\title{
Structural Control of Ore Deposits: The Role of Pre-Existing Structures on the Formation of Mineralised Vein Systems
}

\author{
Alain CHAUVET \\ CNRS-UMR 5243, Géosciences Montpellier, University of Montpellier, cc 60, \\ 34095 Montpellier CEDEX 5, France; alain.chauvet@univ-montp2.fr; Tel.: +3-34-6714-4857
}

Received: 29 October 2018; Accepted: 15 January 2019; Published: 17 January 2019

\begin{abstract}
The major role played by pre-existing structures in the formation of vein-style mineral deposits is demonstrated with several examples. The control of a pre-existing decollement level on the formation of a crustal extension-related (collapse) gold deposit is first illustrated in the Quadrilátero Ferrífero from Brazil. Shear zone and decollement structures were also examined and shown to control veins formation by three distinct processes: (i) re-aperture and re-using of wrench shear zones in the case of Shila gold mines (south Peru); (ii) remobilisation of metal in volcanic-hosted massive sulphide (VHMS) deposit by subsequent tectonic events and formation of a secondary stockwork controlled by structures created during this event (Iberian Pyrite Belt, Spain); (iii) formation of economic stockwork by contrasting deformation behaviours between ductile black schist versus brittle more competent dolomite (Cu-Ifri deposit, Morocco). Two examples involve changing of rheological competence within zones affected by deformation and/or alteration in order to receive the mineralisation (case studies of Achmmach, Morocco, and Mina Soriana, Spain). The last case underscores the significance of the magmatic-hydrothermal transition in the formation of mesothermal gold deposits (Bruès mine, Spain). All these examples clearly demonstrate the crucial role played by previously formed structures and/or texture in the development and formation of ore deposits.
\end{abstract}

Keywords: vein; structure; textures; infilling; breccia; comb quartz; pull-apart; exploration; pre-existing structures; decollement

\section{Introduction}

Numerous studies have been devoted to the process of vein formation mainly because of their significance in term of tectonics and deformation (stress and strain determination), e.g., [1-5], but also because of their significant economic interest in the case of metal-bearing veins, e.g., [6-8]. Several works have concentrated on the external geometry of veins and their relationships with the mode of opening and, consequently, the local or regional stress field during vein formation [9-11]. Complementary studies have also integrated information that can be deduced from vein infilling textures, such as the classical tripartite division in syntaxial (inward growth), antitaxial (outward growth) and stretching veins (complex pattern with no consistent growth direction) [12-14]. In economic geology, and particularly in vein-type deposits, the study of the nature and texture of vein infilling is particularly important because it lies at the base of the ore-forming process itself. No recent works have been concerned by this kind of analysis. The latest contributions [15-17] only deal with the internal texture of ore deposits without considering the (external) geometry of the veins themselves.

This paper, as an introduction to the Minerals Special Issue "Structural Control of Ore Deposits, Theory and Reality" focuses on the relationships between the shape and internal texture of ore-bearing veins with the objectives to better understanding vein formation processes and, consequently, to 
improve mining exploration strategies. I will present and discuss seven case studies of metal-bearing veins with different modes of formation that highlight the role of pre-existing features on their development. This aspect seems to be frequently underestimated, at least in the case of vein deposits, and this work aims to demonstrate its significance in the development of exploration and exploitation programs. The re-using of some previously formed structures has, in that case, a significant but passive role with respect to the formation of the economic feature. This concept is already exemplified in another contribution of this volume [18]. Each of the seven cases presented herein include a brief overview of the regional geology and deformation history, followed by a detailed geometrical and textural analysis of ore-bearing veins and a regional-scale genetic model that integrates these data. The relationships between neo-formed structures versus pre-existing ones will be highlighted in each case as well as its implications for regional vein distribution and, consequently, exploration programs.

\section{Methodology: Structural Analysis Applied to Metallogeny}

The literature on structurally controlled vein-style mineral deposits, e.g., [7,8], has provided a number of theoretical concepts that link vein orientation and geometry with respect to the tectonic stresses. However, only a few studies have integrated regional tectonic context, vein shape and internal vein texture [19-21].

The present work emphasises the importance of multidisciplinary work on vein-style mineralisation combining (micro) structural, textural, and mineralogical analyses, in order to answer to the following questions:

- What tectonic context is responsible for trap formation? (the geometrical analysis)

- What is the mode and condition of filling? (the internal analysis)

\subsection{Trap Formation}

Figure 1 illustrates three classic tectonic traps found frequently in the literature [22] and described in this work. We can distinguish (i) vein opening during flexural folding of multilayers with contrasted lithology with a void being created within competent levels by (re-)opening of the coeval axial plane cleavage (Figure 1a); (ii) gaps formed by differential shearing due to fracturing and boudinage of more competent layers leading to stockwork development (Figure 1b); (iii) aperture controlled by extensional relay (pull-apart) associated with either fibrous/comb veins or breccia veins (Figure 1c). The factors determining these alternative types will be treated further. These three mechanisms are the ones most commonly invoked to explain vein formation in economic interest with probably more cases resembling Figure 1c. Figure 2 illustrates the mechanism of re-using a previously formed structure left lateral shear zone showing a main shearing vein with breccia and secondary cleavage parallel veins that opened during a subsequent tectonic event with different stress directions as when the shear zone originally formed. Internal filling for each stage is drastically different: brecciation without infilling in the case of the main shearing plane and comb or fibrous crystallisation in the secondary cleavage parallel veins (Figure 2). 
a. Void formation during folding

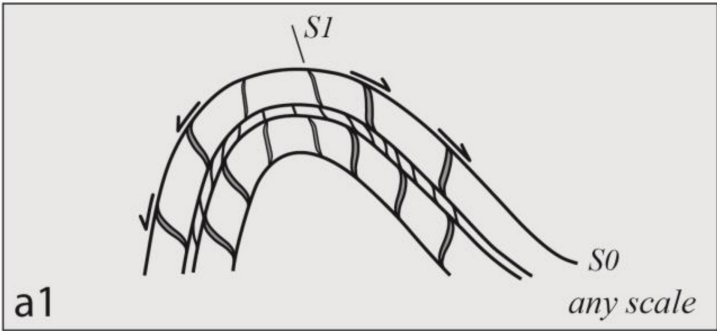

\section{b. Stockwork formation in accomodation of shearing}

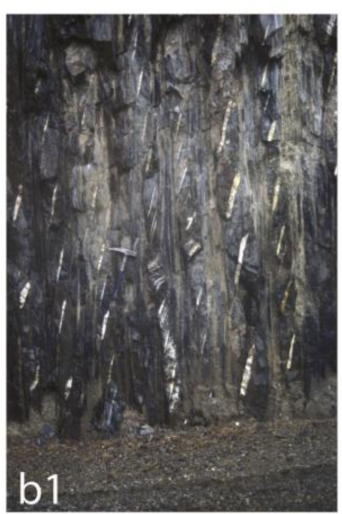

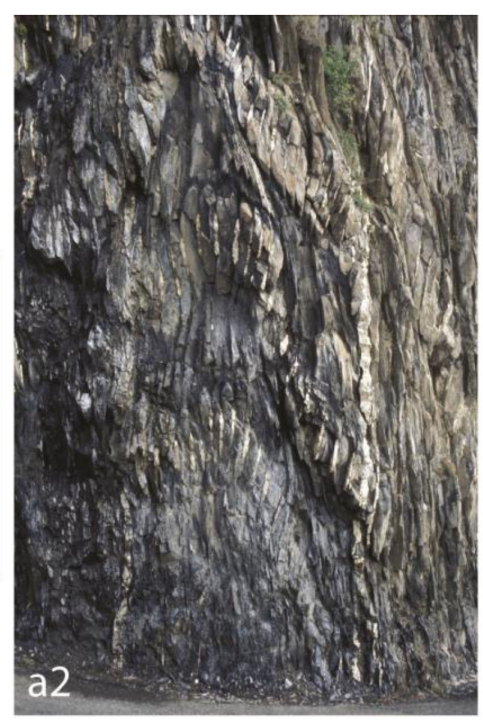
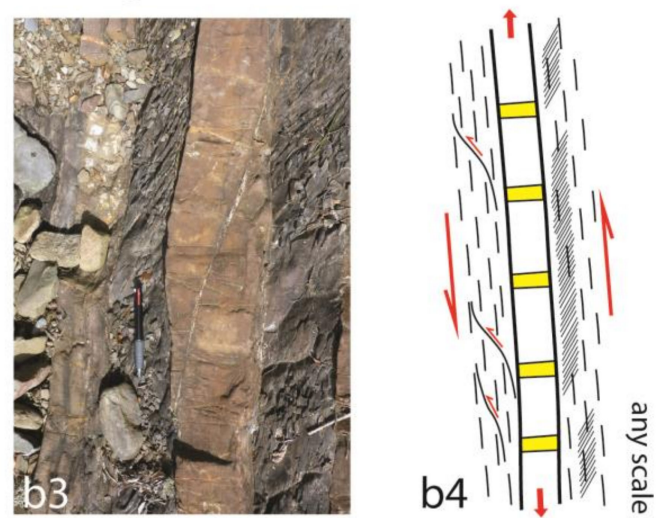

\section{c. Trap opening within extensional relay}

Fibrous or comb infilling

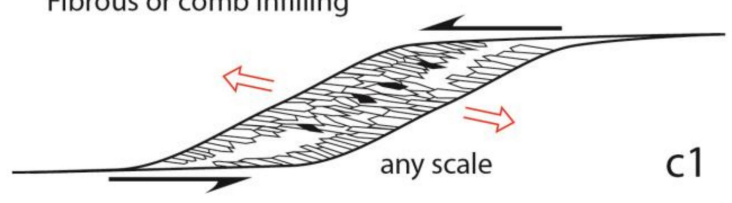

Dilational breccia

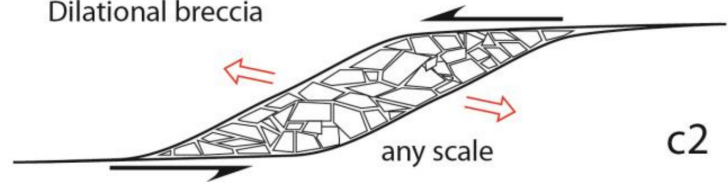

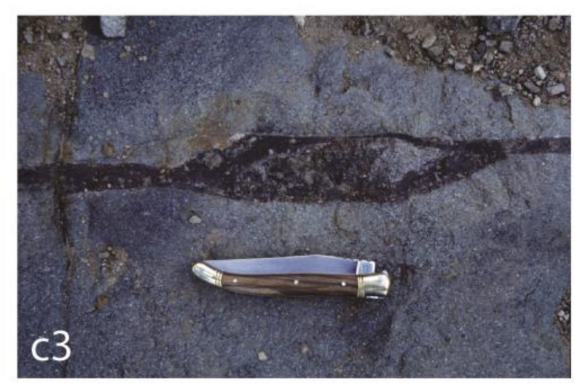

c3

Figure 1. Three examples of traps and voids mode of formation. (a) Model of formation of sigmoidal veins by antithetic bedding-controlled gliding during fold development (a1). Example from the Bourg-d'Oisans area (a2). (b) Stockwork formation in accommodation of shearing affecting some multi-layers rocks with contrast of competence (b1, b2 and b3). Conceptual sketch (b4) in which yellow veins represent the stockwork formed in more competent layers. (c) Trap opening within left lateral pull-apart (c3). The two sketches $\mathbf{c 1}$ and $\mathbf{c} 2$ illustrate the process and show the two types of filling encountered within these structures. See text for explanation.

It may be surprising to see that Figures 1a and 2, propose that a cleavage plane, reputed to be a plane of maximum flattening, is used as a syntectonic trap for mineralisation during its formation. 
However, this solution has been adopted and demonstrated within two works on this topic [23,24]. We will see, in the following examples, what are our arguments to defend this unconventional concept. The case of Figure 2 should not raise the same concern because, here, cleavage serves as a receptacle for ore concentration in a late deformation event that causes dilation parallel to a pre-existing cleavage.
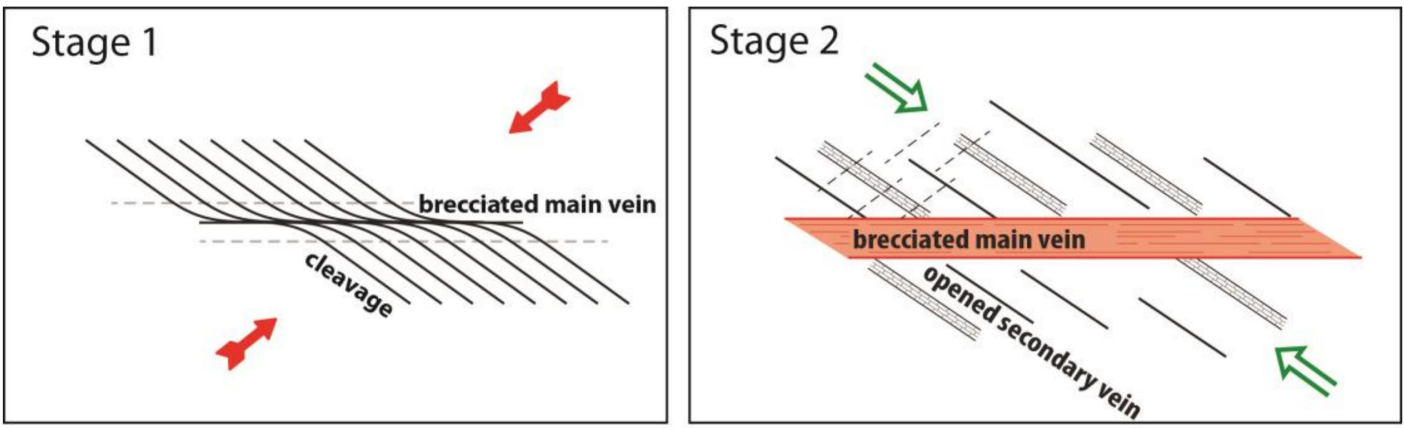

Figure 2. Example of re-using and re-opening of a previously formed left-lateral shear zone during two different states of stress. Red and green arrows correspond to the shortening direction of each stage. Note that main infilling is realised during stage 2.

\subsection{Internal Texture}

The following internal texture of ore-bearing veins can be distinguished.

- Massive or buck texture: rare examples of this texture have been interpreted to result where voids are filled after, not during their formation. This texture is frequently characterised by euhedral or anhedral grain of variable size throughout the vein [15] due to uniform growth rates. Grain orientation can also be highly variable. In fact, such a texture provides limited information about the tectonic conditions prevailing during vein formation.

A fibrous or comb crystal shape corresponds to crystallisation coeval with vein opening and represents the more interesting texture for the topics of this study (Figure 3). Whether comb or fibrous textures develop depends on the rate of trap opening versus crystal growth (see below).

Comb quartz is commonly related to (Figure 3a) (i) a supersaturated fluid invading an open space (the initial fracture) with competitive crystal growth normal to the walls $[16,25,26]$; and (ii) a slow opening rate of the fracture keeping pace with the rate of crystal growth [15,27]. Veins formed by this process only differ from crack-seal veins [28-30] by the lack of fibrous crystallisation and evidence for incremental cracking, such as successive and parallel inclusion trails. Indeed, fibrous textures result from the same process as comb infilling, except that crystal growth is incremental instead of continuous. In this case, the crack is caused by fluid overpressure and crystallisation occurs immediately after the aperture with a unique free direction for crystal growth-the vein centre. The succession of cracking event and, consequently, of immediate filling, explains the continuous crystallisation and, therefore, the fibres (Figure 3b) [31]. By contrast, comb texture is supposed to form where the rate of crystallisation is lower than the opening rate. In this case, the crystallisation only covers the vein wall, and crystals are larger as in the case of fibrous veins and can develop during multiple growth stages (Figure 3a), sometimes associated with a change of fluid composition and chemistry [15]. It is still uncertain, though, if all fibrous veins form by the crack-seal mechanism, or whether they can also form by continuous fibre growth, where diffusion keeps pace with the rate of dilation [26,32]. 


\section{a. Comb texture}
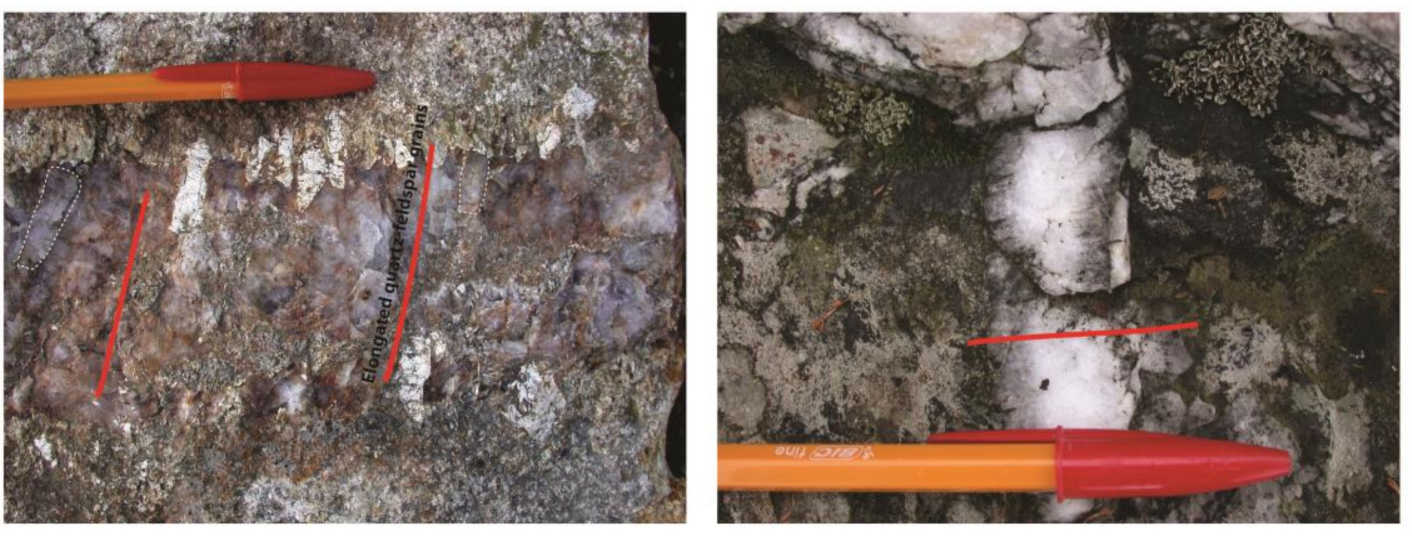

b. Fibrous texture
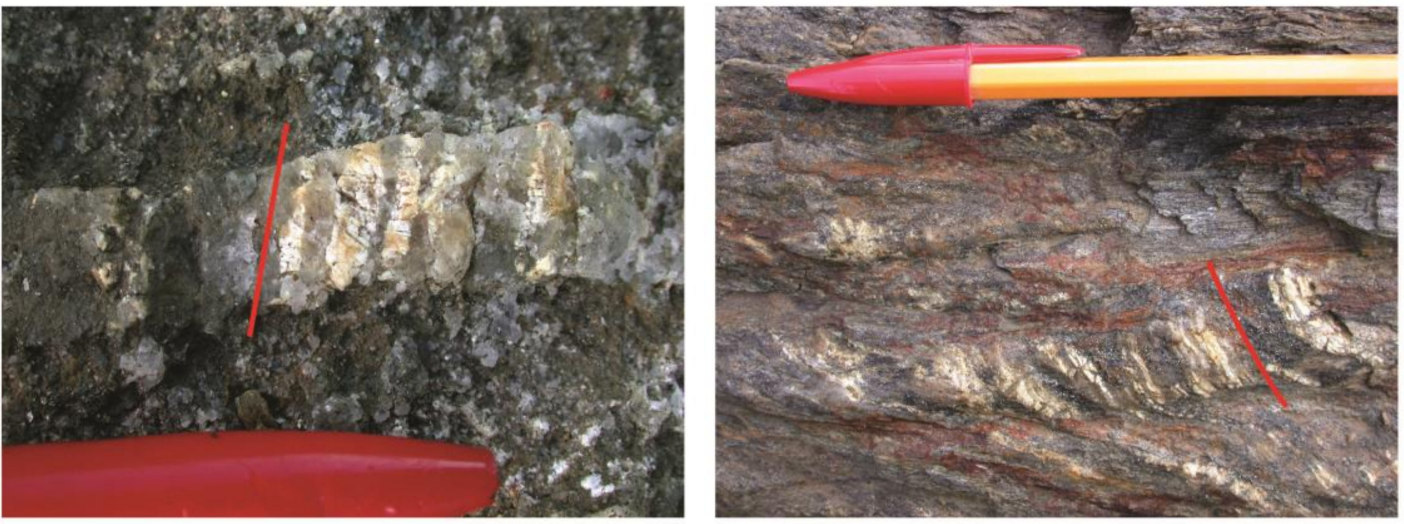

Figure 3. Examples of comb and fibrous textures from the Hercynian mining district of Tras-os-Montes, Galicia, Spain. Red lines illustrate the elongated quartz and feldspar grains indicate the opening direction. Note the difference between fibres that cross-cut the veins and comb grains that do not traverse the vein.

- Breccia textures are witnesses of complex processes for which we have to take into account three parameters based on the recognition between fragments and matrix in order to understand their process of formation:

The nature of the matrix or cement (rock flour, sediment, volcanic, magmatic, hydrothermal, ... );

- The nature and shape of the fragments (circularity, size, distribution, fabrics, monogenic or polygenic, lithological nature);

$\bigcirc \quad$ The relationships between fragments and matrix/cement (matrix-supported or grain-supported).

As a function of these three parameters, a genetic classification of breccia has been proposed by [33], which is frequently used as an indicator of the conditions of vein formation [34-39]. The most used in lode-related economic geology are the tectonic, hydrothermal, magmatic, collapse-related, crackle, hydraulic and dilational breccia. Their recognition is based on the following features (Figure 4):

- $\quad$ Tectonic breccia is easily recognisable because of grain reduction and oriented fragments (Figure 4a). Depending of its maturity (function of the strain intensity), fragments can be in contact (grain-supported breccia, beginning of fragmentation and subsequent comminution) or finally flooded in a largely developed matrix (matrix-supported breccia). Tectonic breccia is more 
frequently monogenic. With respect to the intensity of the deformation and the presence or lack of clay minerals, they can be called cataclasite, ultracataclasite or gouge.

- Hydrothermal breccia is characterised by more-or-less rounded fragments of the same nature (not always) in place within a hydrothermal matrix. Frequently, the final voids are filled by cement that can frequently contain some metals in economic contexts (Figure $4 b$ ).

- Magmatic breccia is more or less similar to the hydrothermal ones, except that the matrix is only magmatic and there is no cement (Figure 4c). In this case, the fragments are rounded and never in contact (matrix supported breccia). Due to the explosive processes, magmatic breccias are frequently polygenic. The differentiation between matrix and fragments, both magmatic, is sometimes difficult, especially in thin sections.

- Collapse breccia is easy to recognise because they show a large variation of fragment size, the presence of cement, and grain-supported texture (Figure 4d). Their geometry is clearly consistent with their mode of formation: (i) collapse of the fragments in response to an underlying explosion or void formation by dissolution and (ii) posterior cementation.

- Crackle breccia is an early stage of what is going becoming a hydrothermal, tectonic or hydraulic breccia. Due to their mode of formation, they are monogenic, with a low matrix and they can be assimilated to early fragmentation in response to either tectonic stress or fluid-related fracturing. Some parts frequently exhibit the host rocks being not totally disrupted whether other parts can be more mature with well-expressed breccia texture (Figure 4e).

- Hydraulic breccia is the result of hydraulic fracturing. It exhibits typical jigsaw geometry with a monogenic character and a very regular pattern (Figure $4 \mathrm{f}$ ). The matrix is well represented, and fragments are never in contact. The mode of formation is only due to cracking due to fluid overpressure. Dilational breccia forms within extensional relay or pull-apart (Figures 1c, 2 and 5). In this case, breccia formation is explained by the fact that void creation causes the fragmentation of the hosted rock affected by the pull-apart formation. Fragments are weakly transported and sometimes rotated and the occurrence of cement is common. Why some pull-aparts are filled by fibrous/comb crystals or dilational breccia remains an open question (Figure 2c). The outcrop in Figure 5 can help because the two types of infilling have been observed within the same structure. Since dilational breccia has been observed on the wall of the secondary formed comb infilling (Figure $5 b$ ), we suspect that both types of texture can be developed in the same structural context. Field relationships demonstrate that dilational breccia texture can form at the beginning of the process, when rates of aperture are weak and late and rapid opening can explain the superposition of fibrous/comb infilling. Indeed, the alternative formation of dilational breccia or comb texture in the core of pull-apart can appear as a function of opening velocity, crystal growth rate, and fluid saturation. We guess that dilational breccia in the core of pull-apart can be created during all main tectonic contexts (i.e., compression, extension, transtension, etc.) and not restricted to the only case of wrench tectonics, as this has been established for the large-scale pull-apart-related basin formation along crustal-scale faults [40]. 


\begin{tabular}{|c|c|}
\hline $\begin{array}{l}\text { a. Tectonic Breccia } \\
\text { Characteristics: } \\
\text { - grain reduction } \\
\text { - fragments preferred orientation } \\
\text { - frequently monogenic } \\
\text { Process of formation } \\
\text { - Fault activity with comminution } \\
\text { and grain reduction }\end{array}$ & 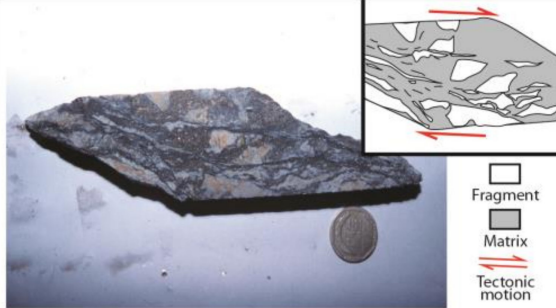 \\
\hline $\begin{array}{l}\text { b. Hydrothermal Breccia } \\
\text { Characteristics: } \\
\text { - rounded monogenic fragments } \\
\text { - matrix-supported breccia } \\
\text { - occurrence of matrix and final } \\
\text { cement } \\
\text { Process of formation } \\
\text { - Hydrothermal fluid emplacement }\end{array}$ & $\underset{c c}{\text { Matri }}$ \\
\hline $\begin{array}{l}\text { c. Magmatic Breccia } \\
\text { Characteristics: } \\
\text { - rounded polygenic fragments } \\
\text { - matrix-supported breccia } \\
\text { - No cement, magmatic matrix } \\
\text { Process of formation } \\
\text { - Explosion link with magmatic } \\
\text { activity }\end{array}$ & $\begin{array}{c}5 \\
\text { Polyg } \\
\text { Pragm } \\
\text { Fagm } \\
\text { Magm } \\
\text { Matt } \\
\text { fis } \\
\text { Explos }\end{array}$ \\
\hline $\begin{array}{l}\text { d. Collapse Breccia } \\
\text { Characteristics: } \\
\text { - systematic cement } \\
\text { - grain-supported breccia } \\
\text { - polygenic or monogenic } \\
\text { Process of formation } \\
\text { - Collpase of the fragments and } \\
\text { subsequent cementation }\end{array}$ & Frogme \\
\hline $\begin{array}{l}\text { e. Crackle Breccia } \\
\text { Characteristics: } \\
\text { - monogenic } \\
\text { - low matrix } \\
\text { Process of formation } \\
\text { - Beginning of fragmentation due to } \\
\text { tectonics or fluid overpressure }\end{array}$ & 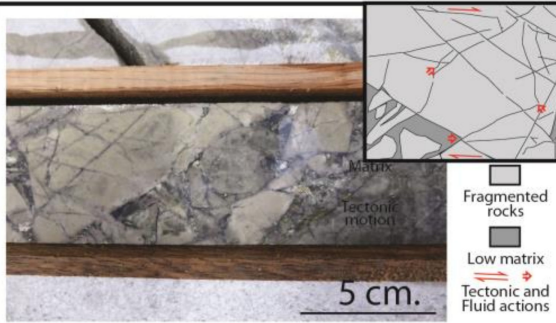 \\
\hline $\begin{array}{l}\text { f. Hydraulic Breccia } \\
\text { Characteristics: } \\
\text { - jigsaw geometry } \\
\text { - monogenic character } \\
\text { - matrix-supported breccia } \\
\text { Process of formation } \\
\text { - Cracking by fluid overpressure }\end{array}$ & 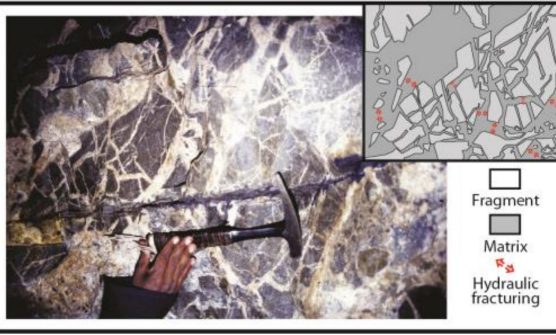 \\
\hline
\end{tabular}

Figure 4. Breccia texture classification frequently used in ore geology. Each case is described in detail in the text. A conceptual sketch is indicated for each photograph in order to correctly interpret the image. The scale of these sketches is the same as the corresponding photograph. In red, some indications about the process responsible for breccia formation are provided. 


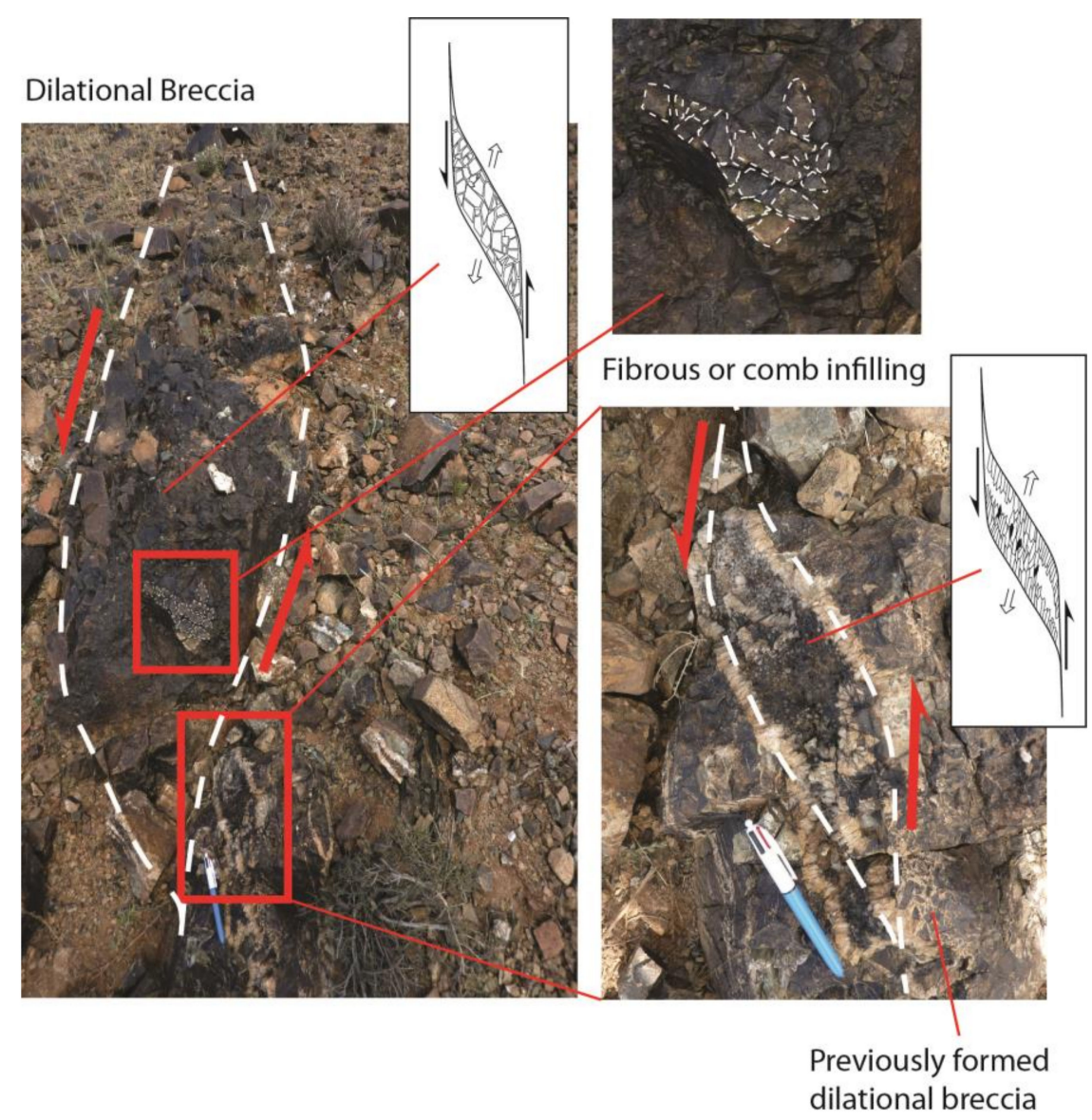

Figure 5. Superposition of dilational breccia texture and fibre/comb ones within similar left-lateral pull-apart structures (see text for explanation of the cause of occurrence of fibrous or breccia texture).

\section{Vein Formation Process and Tectonics: Examples from Ore Deposit Study}

\subsection{Gold Concentration during Collapse Tectonics}

A pluridisciplinary approach has been undertaken with the study of gold-bearing quartz veins of the Quadrilátero Ferrífero (Minas Gerais, Brazil) [41]. This deposit has been classically interpreted as a strongly deformed pre-tectonic one on the basis of the sigmoid shape (Figure 6) exhibited by ore-bearing veins and, also, as a typical Archean orogenic gold deposit [42]. The internal vein texture study combined with regional tectonic constraints suggests an alternative model in which veins are formed in response to the late collapse tectonics, later with respect to the nappes emplacement [41]. During these movements, sigmoid voids were created and filled by elongate quartz grains associated with sulphides, tourmaline and carbonates (Figure 6a). Such a normal motion has been facilitated by the existence of mica-rich levels (Figure $6 \mathrm{~b}$ ) that underline the foliation of the hosted meta-sediments. This result has been obtained essentially because the internal texture has revealed that quartz grains are un-deformed and that their formation was the result of only one opening episode, within free tectonic stress context. The superposition of sigmoidal pull-apart formation on earlier shearing deformational event has been clearly observed (Figure $6 \mathrm{c}$ ). The process of formation is similar to the conceptual sketch of the Figure 2 with re-using and re-opening of pre-existing shear zone. Here, the sigmoidal shape of the mica-rich level due to the earlier thrust event is re-used. Inferred hydrothermal effects were responsible for the formation of illite, sulphides, carbonate, garnet and green biotite within the matrix. 


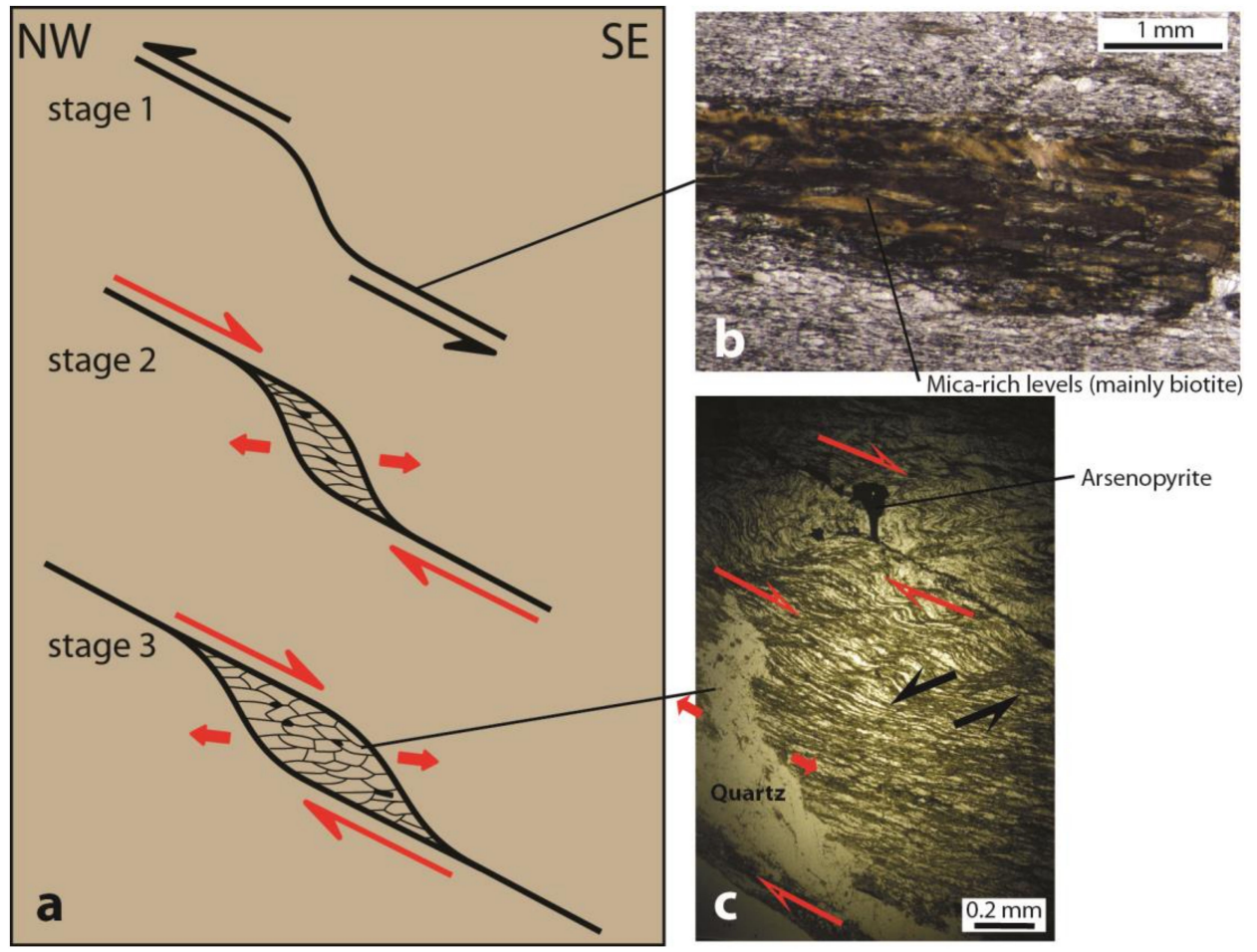

Figure 6. (a) Formation of sigmoid vein during late-orogenic collapse tectonics (red arrows) within the Quadrilátero Ferrífero (Minas Gerais, Brazil). Note that vein re-used an early level formed by mica alignment related to the nappe emplacement $(\mathbf{b})$. The sigmoidal shape reflects thrust-related emplacement (black arrows). Extensional pull-apart post-dated thrust-related structures and controlled gold-bearing quartz-sulphide veins (c).

This study demonstrates that the Ouro Preto mesothermal gold deposit was formed in context of late-orogenic collapse, drastically different from the conventional auriferous shear-zone model, model that has been intensively used during the 1990s [43,44]. A recent study confirms this hypothesis by the demonstration of resetting of older zircons by ca. $496 \mathrm{Ma}$ old hot fluid rock interactions in the area of Passagem [45].

This example clearly illustrates the importance of the systematic observation of the internal vein texture before concluding on the mechanism of vein formation based only on the geometrical analysis.

\subsection{Vein Opening and Filling Controlled by Regional-Scale Structures within Volcanic Domains}

The Shila-Paula district is one of the numerous Au/Ag low sulfidation epithermal one of Southern Peru. It is characterised by numerous veins hosted by the tertiary subaerial volcanics of the Western Cordillera. Field studies shown that most of the mineralised bodies consist of the systematic association of main E-W veins and secondary N120-135 $5^{\circ}$ veins (Figure 7) [46]. Two main stages of ore deposition are identified [47]. Stage 1 consists of a quartz-adularia-pyrite-galena -sphalerite-chalcopyrite-electrum-Mn silicates and carbonates assemblage that fills the main E-W veins (Figure 7a,b,e). Stage 2, also called the bonanza stage, carries most of the precious mineralisation and consists of quartz, Fe-poor sphalerite, chalcopyrite, pyrite, adularia, galena, tennantite-tetrahedrite, polybasite-pearceite, and electrum. This stage is mainly observed within secondary veins, in final geodic filling (Figure 7c,f) and in veinlets that cut stage 1 assemblage (Figure $7 d, g$ ). In main veins, the ore is systematically brecciated, whereas tectonic-free environment characterised the filling of secondary veins. The age of veins was estimated to be around 10.8 Ma using 40Ar/39Ar ages on adularia crystals from different veins [47].

A two-stage model is proposed to explain vein formation. The first stage was assumed to correspond to the development of E-W sinistral shear zones and associated $\mathrm{N} 120^{\circ} \mathrm{E}$ cleavages under 
the effects of a NE-SW trending shortening direction, which has been previously recognised at the Andean scale (Quechua II phase) (Figure 7a). These structures serve as a receptacle for the emplacement of stage 1 ore assemblage that was brecciated during ongoing deformation (Figure $7 \mathrm{~b}$ ). The second event operates a re-opening of the previously formed structures under a NW-SE trending shortening direction that allowed the re-opening of pre-existing cleavage and the formation of scarce $\mathrm{N} 50^{\circ} \mathrm{E}$ trending S2 cleavages (Figure 7c), such as in the model in Figure 2. This stage was followed by the bonanza ore emplacement both within geodes in core of the main E-W veins and in secondary N120- $135^{\circ}$ E veins (Figure 7d). The two directions of shortening, NE-SW for the first event and NW-SE for the second one, are also recorded by the orientation of fluid inclusion planes within quartz crystals from the host rocks.

This study represents a unique example, constrained by combined tectonic, textural, mineralogical, geochronological, and fluid inclusion data, of the establishment of a complete model of deposit formation in which the re-using of previously formed tectonic features as a factor of gold concentration in epithermal environment is evidenced.

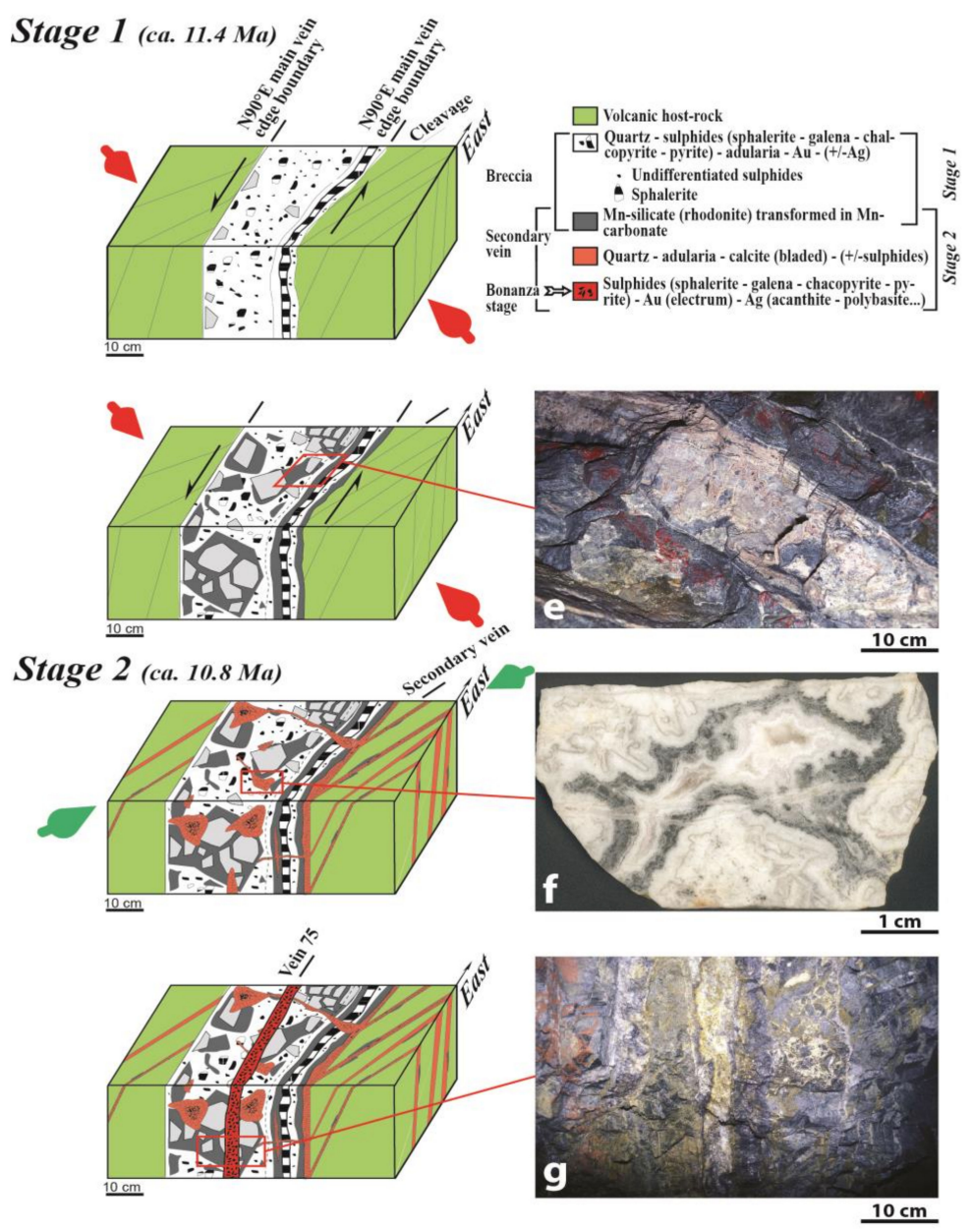

Figure 7. Example of vein formation by the re-using of pre-existing structures within the Volcanic domain of South Peru (see text for explanation). (a) Formation and filling of sinistral shear zone and creation of associated cleavage under the effect of NE-SW shortening direction (red arrows). (b) Formation of Mn-rich breccia under the same shortening direction. (c) Formation of secondary veins by re-opening of the cleavage by $\mathrm{N} 120^{\circ} \mathrm{E}$ trending shortening direction (green arrows). Formation of geodic structures filled by stage 2-related paragenesis and subsequent "bonanza" stage and richer veins (Veta 75$)(\mathbf{d})$. 


\subsection{Tectonic Stockwork Development in Fold and Thrust Belt Environment}

\subsubsection{The Iberian Pyrite Belt Example}

The Variscan Iberian Pyrite Belt is affected by a continuous and progressive deformation that integrates the formation of south-directed folds and thrust vs. north-verging features [48]. In the light of this structural model, a microtectonic, textural, and mineralogical study of the stockworks associated with the volcanic-hosted massive sulphide (VHMS) deposits has been performed [24].

In addition to the first and primary stockwork assimilated to represent the feeder veins of the VHMS, a second stockwork occurs under the form of undeformed veins frequently emplaced within cleavage and shear planes characteristic of the south-verging deformation (Figure 8a). The characteristic mineral of both stages is pyrite. Within the primary stockwork, sulphides have Co-As-rich rims that are interpreted as overgrowths formed during the second event. Instead of that, the base metal assemblage that characterised the second stockwork is similar to the one seen within the primary stockwork, especially when developed at its contact. Conversely, second stockwork is observed far away from the primary one and VHMS is only filled by quartz and pyrite. The internal texture indicates that pyrite is systematically fractured by ongoing deformation and quartz fibres develop within asymmetric pressure consistent with the south-verging tectonics. Geochemical analysis of pyrites emphasises the discrimination between both stockworks and pyrites from early stockwork are S-depleted/Fe-enriched with respect to those of the second stockwork. Since sulphides are located within the cleavage and shearing plane (Figure $8 b, c$ ) and quartz fibres systematically develop around pyrite grains, the second stockwork is interpreted as developing during the south-directed tectonics [24]. Moreover, the second stockwork has been encountered within axial plane cleavage related to the south-directed tectonics (Figure 8d), similar to the conceptual trap formation within cleavage of Figure 1a. This is strongly confirmed by sulphide textural analysis that demonstrates the co-existence of deformational effects (pyrite subgrain boundary, blow-up pull-apart, Figure 8e) and post-tectonic pyrite overgrowth (Figure 8f). If the mineralised fluids responsible for this second stockwork result from the VHMS and early stockwork remobilisation or from external metamorphic source remain uncertain.

\subsubsection{The Moroccan Palaeozoic High-Atlas Example}

The mineralised district of the High Seksaoua (Western High Atlas, Morocco) is characterised by a lithological succession marked by an alternation of schists and limestones attributed to the Cambrian and affected by the Hercynian orogeny. The existence of stratiform masses of pyrite first suggests that this deposit can be a VHMS (Figure 9a) [49]. However, copper mineralisation, the first economic goal, is absent from the stratiform pyrite levels but systematically localised close to the dolomite/black schist contact in which a top-to-the-N-NW décollement-type tectonics [50,51] has been identified (Figure $9 b$ ). The economic mineralisation is a syntectonic stockwork (Figure 9c,d) formed in response to this top-to-the-N-NW shearing event that only affects the black schist layers (Figure 9). We suggest that vein formation is a brittle response, within competent dolomite levels, of the ductile deformation that affects the black schist (Figure 9a) [51], as described in the conceptual model of the Figure 1b.

This tectonic has been correlated to the late-Hercynian tectonics on the base of the Permo-Triassic age (ca. $270 \mathrm{Ma}$ ) given by ${ }^{40} \mathrm{Ar} /{ }^{39} \mathrm{Ar}$ dating realised on white micas related to the stockwork [51]. This important result questions the syngenetic interpretation accepted until now for this mineralisation, and allows us to propose a new model of formation in which the "décollement"-type tectonics represent the main factor of ore concentration.

The Iberian and Moroccan examples illustrated the role of decollement structures in the emplacement of stockworks associated with metal-rich minerals. If no economic concentration can be deduced from the remobilisation process during Hercynian orogeny in the case of the South Iberian Pyrite Belt and, moreover, compared to the huge metal mass represented by the VHMS, a similar process applied to the Ifri deposit led to the formation of the $\mathrm{Cu}$-rich economic orebodies. 


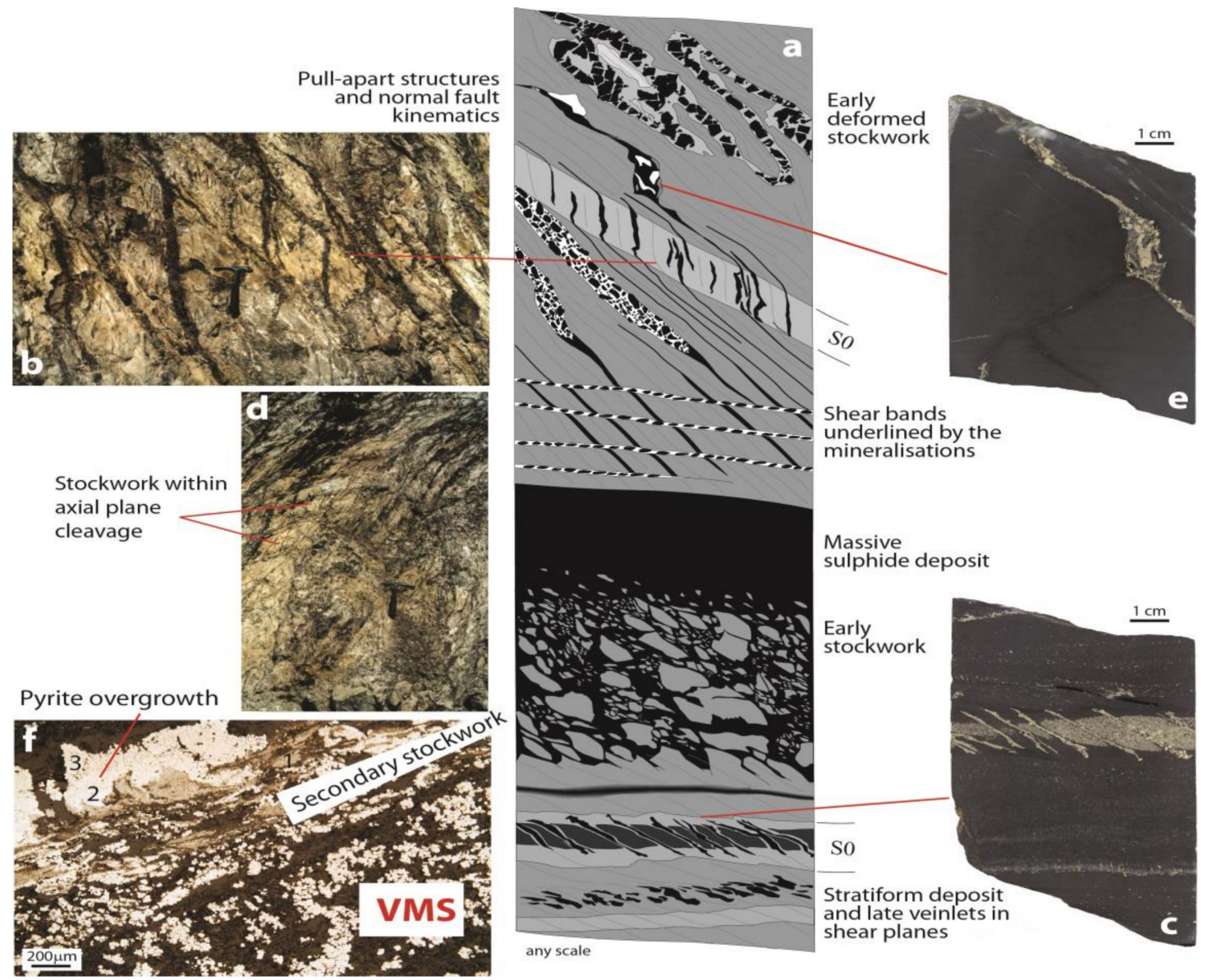

Figure 8. Schematic illustration showing the relationships between first stockwork and secondary one around the VHMS of the Iberian Pyrite Belt (south Spain). (a) Schematic distribution of the different stockwork and mineralised features close to a VHMS body. Occurrence of second stockwork within meter-scale shear bands (b) and within axial planar cleavage (d). (c) Stratiform pyrite-rich level cut by secondary pyrite-rich veins. (e) Small pull-apart filled by syntectonic quartz and pyrite. (f) Pyrite metablasts and overgrowths ( 2 and 3 ) formed close to a synkinematic second stockwork. 


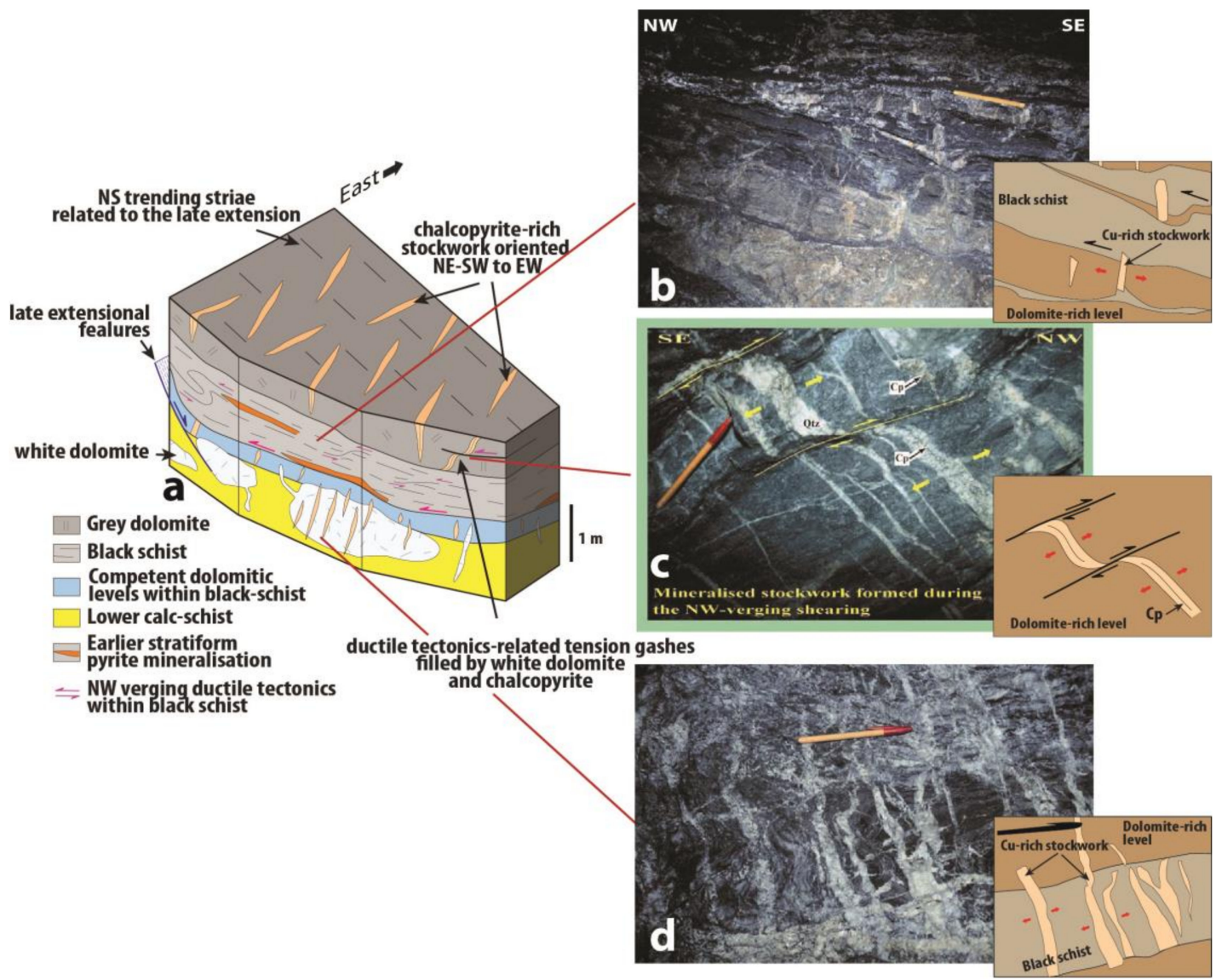

Figure 9. (a) Illustrations of the Ifri $\mathrm{Cu}$ mine model showing some images of the $\mathrm{Cu}$-rich stockwork formed in response of ductile decollement within black schist. Each photograph is associated to a schematic cartoon in order to explain the geological process. (b) Example of vein formation within competent dolomite rich level in response of the ductilely deformed black schist. (c) Opening of chalcopyrite/quartz-rich veins due to NW-directed shearing. (d) Stockwork formation by contrasted behaviour of dolomite and black schist.

\subsection{Rheological Control on Ore Concentration}

In this chapter, we illustrate the significant role of rheological conditions on the development of ore deposits. Here, we will highlight two cases in which changing rheological conditions due to intensive tourmaline-rich alteration process favoured the formation of lode-related deposits.

\subsubsection{Sn-rich Breccia Formation of the Achmmach Prospect (Moroccan Central Massif)}

The Achmmach tin mineralisation occurs within the NE part of the Massif Central domain of Morocco, hosted by Ordovician, Silurian, and Devonian low-grade meta-sediments affected by the Hercynian deformational events, weakly represented in this area. The region concerned by the deposit exhibits a regular, N030 $-045^{\circ} \mathrm{E}$ trending cleavage mainly within the Silurian calc-schists. The mineralisation is the result of a long-lived process that includes four events that occurred in a transtensional tectonic regime associated with the late magmatic-hydrothermal evolution of the Hercynian orogeny (see details in [52]).

- The first event is the formation of tourmaline-rich halos in core of the calc-schist. These halos have ellipsoidal shape resembling tension gashes and are supposed to have formed during E-W trending shortening. Since they follow the $\mathrm{N} 070^{\circ} \mathrm{E}$ trend of the cleavage, most halos are "en echelon" and indicators of a right-lateral potential shearing. Conjugate left-lateral "en echelon" 
tourmaline halos also exist but are less common. The rock shown in Figure 10 was collected in the core of one of the alteration halos and is entirely affected by the tourmalinisation.

- $\quad$ The second event is link to the development of right-lateral shearing only in levels affected by the tourmalinisation (Figure 10a,c). It is noteworthy that this deformation is consistent with the same tectonic context and therefore probably result from ongoing transtension controlled by $\mathrm{E}-\mathrm{W}$ shortening. Main shear bands are oriented $\mathrm{N} 070^{\circ} \mathrm{E}$.

- Third, we have evidence of transformation of the previously formed shear band in tourmaline-rich breccia levels (Figure 10a,c). Such levels can reach thickness of 2 or 3 meters. The breccia is matrix-supported with a well-developed tourmaline-rich matrix, and can exhibit some domains with fragment-preferred orientation thus translating to tectonic- and hydrothermal-type breccia.

- The fourth texture is the most important because it is associated with cassiterite and thus representative of the economic stage. Transtension is transformed in extension and normal faults developed with the formation of a clast-supported breccia with numerous voids formation and cassiterite crystallisation (Figure 10b). These mineralised structures are systematically formed at the core of the first breccia levels and always in association with the tourmaline halos.

To conclude, mineralisation in the case of Achmmach prospect is clearly the result of polyphase deformation during the late orogenic evolution of this Hercynian domain and certainly associated with some granite emplacement. Granite remains hidden except for the occurrence of some rare outcrops. Magmatic affinity is demonstrated by the ubiquitous presence of tourmaline at each stage of the process. It is suggested in this case that ore concentration benefitted from the change of rheology due to tourmaline invasion (tourmaline-rich halos). The process was achieved by ongoing successive structures until the final formation of mineralised orebodies (shearing, brecciation and cassiterite crystallisation). 


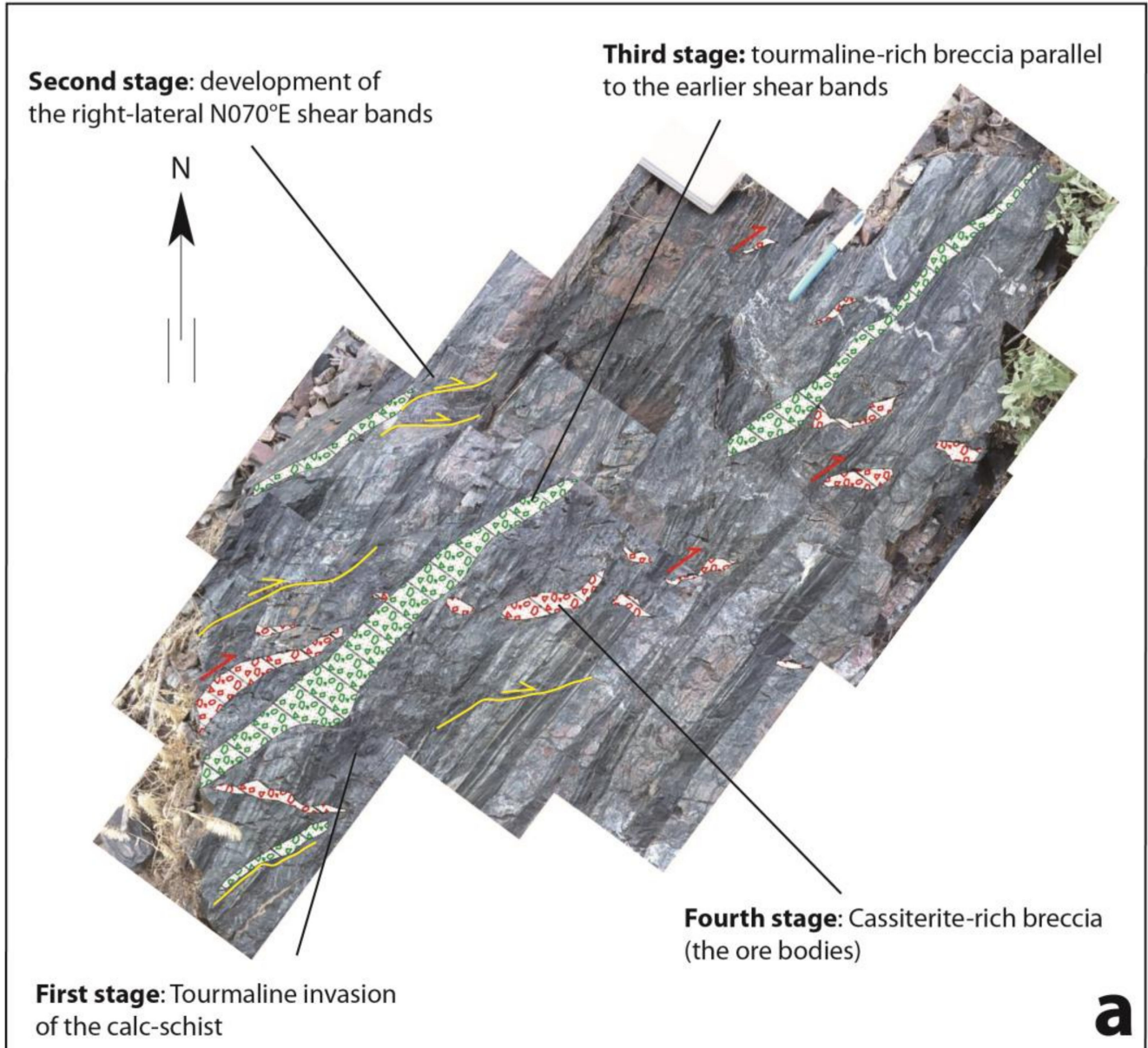

of the calc-schist
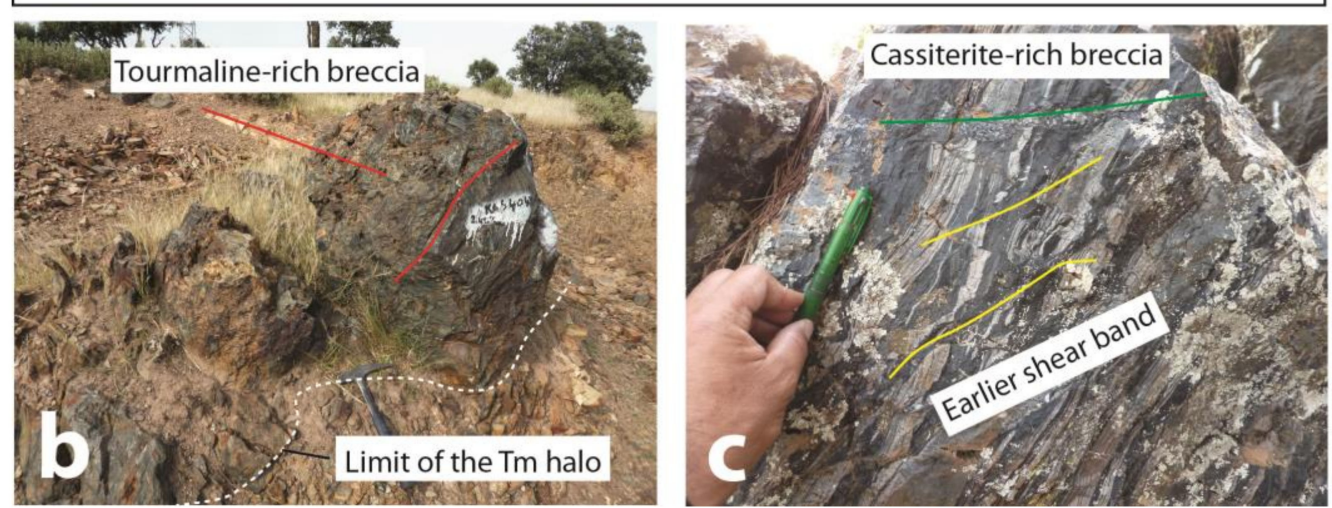

Figure 10. Deposit history and evolution of the four stages that explain the formation of the Achmmach tin deposit (Morocco) recognised in a unique block (a). (b) Image of the "North Zone" area in which the succession of structure can be observed. Note the limit of the tourmaline alteration halo that delimitate the zone where mineralisation developed. (c) Parallelism between ductile shear bands and mineralised breccia showing that breccia re-used the earlier plane of deformation to develop.

\subsubsection{The Sn-W-rich Perigranitic Mineralisations of Beariz (Galicia, Spain)}

The Hercynian orogenic cycle is reputed for abundant calc-alkaline granites that were emplaced during late orogenic Carboniferous extension (collapse of the thickened crust) [53]. This event also related to an intensive ore formation frequently starting with $\mathrm{Sn}-\mathrm{W}$ mineralisation close to the granitic bodies grading to As-Au towards more distal parts [54]. This event has been called "Or 300" by the French school, and recognised throughout the European Hercynides from the Bohemia Massif to Maghreb [55,56]. In Galicia (NW Spain), the Tras-os-Montes area is a segment of the Hercynian orogen 
and characterised by voluminous magmatic complexes emplaced between 325 and $300 \mathrm{Ma}$ (from G1 to G4 granitic events, [57]). The area is the site of abundant ore deposits (Au, W, Sn, REE). The example shown herein concerns the $\mathrm{Sn}-\mathrm{W}$ deposit of the Mina Soriana in which mineralised veins were formed during a tectonic context dominated by NS extension linked to EW shortening [58]. The veins formed with E-W strike normal to a NS stretching lineation. This phenomenon is clearly exposed within the Mina Soriana outcrop. The Mina Soriana outcrop (Figure 11a) exposes a horizontal sill of leucogranite that was injected into mica schist during the N-S lineation-related tectonic event. Tourmaline halos (50 cm of thickness) are developed along the upper and lower host rocks (Figure 11b). Steeply dipping veins mainly filled by quartz and tourmaline occur normal to the magmatic sill and only within the tourmaline-rich halo (Figure 11c). This indicates that micaschist affected by the alteration had changed its competence and reacted differently than the surrounding unaltered micaschist. Veins are limited to the alteration halo although some of them cross cut the magmatic sill, as in boudinage-related structures (Figure 11a). Since tourmaline grains are aligned N-S within the alteration halo but also at the margin of quartz vein (Figure 11d), all features, i.e., magmatic sill emplacement, tourmaline-rich halo, and quartz vein development, are coeval and controlled by the same tectonic event.

In this case, the different behaviour, as explained in Figure 1b, lies at the origin of vein formation and, hence, of the formation of the Mina Soriana main vein, which outcrops further north, with the same orientation as the small-scale quartz veins and is mined as the main orebody. The difference with Figure $1 b$ is that, in this case, the variation of rheology is not a pre-existing lithological feature, but was created during the same process that produced the ore concentration.

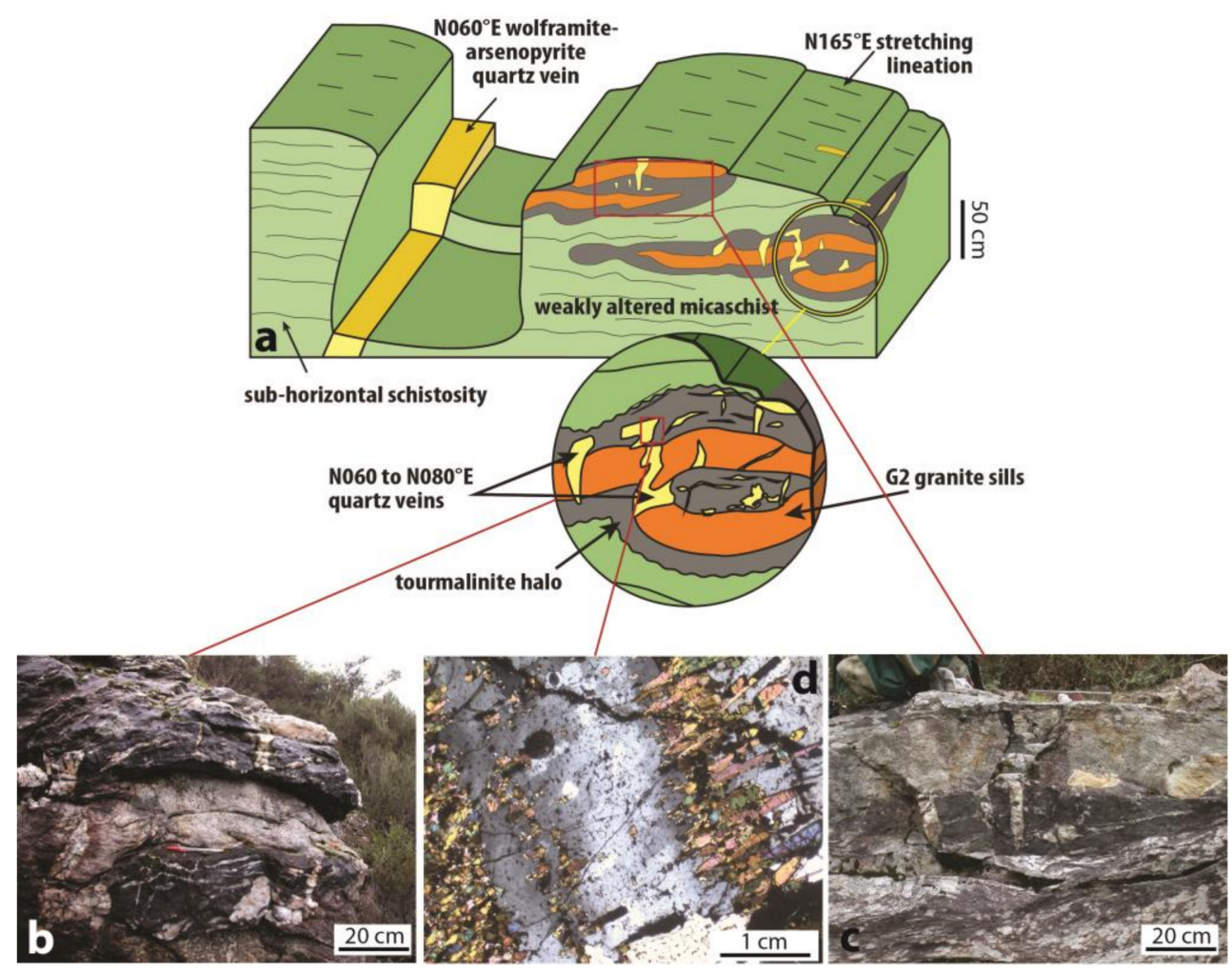

Figure 11. (a) Mina Soriana outcrop, Galicia (Spain), showing the development of mineralised quartz veins thanks to tourmaline-rich alteration halos developed in response to granitic sill emplacement (modified from [59]). (b) Close view of the granitic sill, tourmaline halo and vertical quartz veins. (c) Microscopic view of quartz vein rim showing tourmaline syntectonic growing. (d) Development of vertical quartz mineralised veins limited to the tourmaline-rich alteration halo. 


\subsection{Re-Use of Magmatic Structures: The Magmatic-Hydrothermal Transition}

In the same geological context as the Mina Soriana outcrop, gold mineralisation exists, but close to the G3 granites (the Bruès one, in this case). Gold is associated with quartz-bearing veins that form a regular network emplaced at the Northern cupola of the Bruès G3 granite [58]. This network is also E-W oriented, and veins dip steeply to the north. A link with the G3 granite emplacement has been demonstrated by field and microstructure analysis [57,58]. Few direct arguments have been advanced, but the fact that mineralised quartz veins are systematically emplaced at the contact with the aplite-pegmatite dikes (Figure 12a), which are both controlled by the same structural context, is probably the strongest evidence. In thin sections, the transition from the magmatic stage to the hydrothermal is illustrated (Figure 12b) by an intermediate stage (magmatic-hydrothermal) marked by the crystallisation of K-feldspars that are larger than the ones in the surrounding granite (Figure 12b). In addition, comb shapes confirm that feldspars are syntectonic, neo-formed, and indicate the vein opening direction. Internal fractures show that opening continued after feldspar crystallisation, as evidence for a continuous process. In the centre of the vein and after comb quartz crystallisation (the hydrothermal stage), we find a thin fracture in which small white micas, recrystallised quartz, and sulphides (essentially arsenopyrite and pyrite) occur. White micas and oblique fabrics of recrystallised quartz (Figure 12c) also indicate a normal shearing consistent with the direction of vein opening. This demonstrates that a similar tectonic control prevailed from the late magmatic stages (border of the vein) until the final ore formation (sulphide and white mica at the centre of the vein).

This example confirms the indisputable spatial relationship between early magmatism, late magmatism and hydrothermalism. We highlight, here, the fact that we can follow, mineralogically and texturally, the continuity between late magmatic features (the border of the vein with K-feldspar formation), hydrothermal quartz and late sulphide growth. Once more, the role of the pre-existing network (the magmatic dike on top of the Bruès granite) seems essential for the development of the mineralised system.

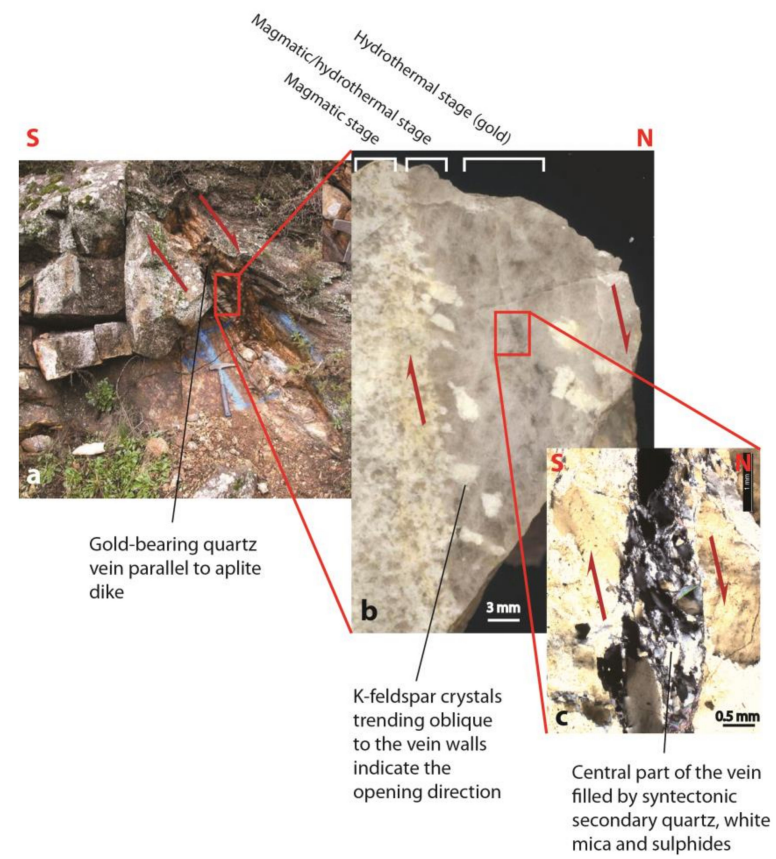

Figure 12. Relationships between gold-bearing quartz vein and granitic dike within the Bruès granite cupola, Galicia. (a) Outcrop view showing the close relationship between quartz vein and granitic dike. (b) Sample view showing the transitional contact between granite and quartz hydrothermal vein. (c) Thin section of the central part of the hydrothermal vein representative of the mineralised stage. Note the occurrence of dynamic recrystallised quartz and white mica indicating a normal sense of shearing. Red arrows indicate the sense of motion. 


\section{Discussion and Conclusions}

(i) Detailed study of geometry and composition of vein associated with ore deposits, combined with mineralogical and textural constraints, is indispensable in order to understand the mode of formation of mineralised systems. In the case of the epithermal veins of the Shila deposit, the model of formation suggests that the formation of the economic deposit is strongly dependent on the pre-existing structuring of the area.

(ii) Without studying internal textures, the interpretation of (external) vein shape can be ambiguous and is not enough to constrain the vein formation process. The example shown of epithermal veins in southern Peru is highly illustrative in this sense. Vein geometry (main vein and associated cleavage) indicates left-lateral shearing, but the opposite conclusion is deduced when taking into account the fact that the veins and, particularly, the secondary ones, are characterised by aperture and stress-free textures that are not consistent with the classical status of what we call a cleavage. This highlights the importance of examining internal vein texture in addition to tectonic and geometrical analyses of any type of ore deposit. A similar conclusion can be drawn from the Passagem gold-bearing veins that were originally interpreted as pre-tectonic but later recognised to have formed during late-orogenic collapse affecting the area. This has significant implications for exploration and exploitation strategies because of the different age and predicted local geometries (angle, elongation) of the potential orebodies.

(iii) Two examples demonstrate the existence of syntectonic stockwork, i.e., metal remobilisation within the huge VHMS of the Iberian Pyrite Belt and the copper mineralisation of the Moroccan High Atlas. Few studies have really demonstrated this hypothesis, but our results provide strong evidence for the synchronism between stockwork formation/emplacement and deformation. Even if secondary stockwork formation does not represent an economic goal within the Iberian Pyrite Belt, such a process led to the formation of the economic orebodies of Ifri (Moroccan High Atlas). This highlights the importance of detailed study of any type of mineralised veins, even if at first inspection they do not seem to be of direct economic interest.

(iv) Although the term "magmatic-hydrothermal transition" may sound old fashioned [60], we demonstrate with the example of Bruès (the last one) that, even though we cannot prove that the mineralising fluid were magmatic, ore formation is intimately associated with the late evolution of magmatic systems in many orogenic and/or mesothermal gold deposits [61]. The Bruès outcrop is a wonderful demonstration of continuity between late magmatic process and hydrothermal mineralisation. It is remarkable that, although detailed absolute geochronology is lacking, the evidence for the same tectonic control from the earliest magmatic stages to the latest hydrothermal stage strongly favours a continuous process. This cannot be enough for affirming the link between mineralisation and granite activity but strongly argued for this and re-addressed the discussion concerning the characteristics of orogenic and intrusion-related gold deposit (IRGD) [62,63].

(v) Competency contrasts in a volume of rock also appear to be a favourable factor for ore concentration and vein formation [64], as shown herein for the Achmmach tin deposit and Mina Soriana W. In these cases, rheological variation was not due to original lithological differences, but induced during early stages of the mineralisation event itself, by heterogeneous alteration. It has been argued that tin mineralisation could not have formed in the Achmmach domain without earlier development of a tourmaline halo within the monotonous calc-schist. These alteration halos, formed during an early stage of transtension tectonics, create a drastic contrast in competency contrast, which controlled the partitioning of ongoing deformation and, eventually, the mineralisation. The case of Mina Soriana is similar, but the link with magmatism is, here, highlighted by the occurrence of a granitic sill responsible for the tourmaline-rich alteration. Nonetheless, in both cases, a link with late magmatic activity can be inferred in view of the above discussion about the role of the magmatic-hydrothermal transition. 
In the light of these results, the importance of tectonic and microtectonic analysis at different scales in modern metallogenic studies is underlined. This work should be realised at the regional scale down to the scale of internal vein textures. The complementarity nature of pluridisciplinary works, even though already adopted in many previous studies, has been again demonstrated by the examples proposed and discussed in this paper. Change of scale and integration within the regional, geological and tectonic context are two additional conditions for a comprehensive analysis. The benefits of such an approach are both fundamental, leading to a better understanding of the mechanism of vein formation process, and economics, leading to better knowledge of specific orebody geometry and distribution and hence highly recommended in any type of exploration program.

Funding: This research was partly funded by Projects CAPES-COFECUB and CNRS GDR Transmet.

Acknowledgments: The mining companies SEIMSA (Iberian Pyrite Belt, Spain), CVRD (Vale group, Brazil), CEDIMIN and BUENAVENTURA (Peru), MANAGEM (Morocco), SMS (Seksaoua, Morocco) and KASBAH RESSOURCES (Achmmach, Morocco) are gratefully acknowledged for their constant help, support and fruitful discussions. L. Badra, L. Bailly, L. Barbanson, Y. Branquet, P. Chaponnière, P. Couderc, M. Dardennes, A. Gaouzi, J.M. Georgel, E. Gloaguen, M. Majhoubi, M. Menezes, J. Onezime, J. Rosas, and J. Tuduri, are tanked for their contribution. Two anonymous reviewers and D. Aerden are kindly acknowledged for their fruitful and constructive review.

Conflicts of Interest: The authors declare no conflict of interest. The funders had no role in the design of the study; in the collection, analyses, or interpretation of data; in the writing of the manuscript, or in the decision to publish the results.

\section{References}

1. Durney, D.W.; Ramsay, J.G. Incremental strains measured by syntectonic crystal growths. In Gravity and Tectonics; De Jong, K.A., Scholten, K., Eds.; Wiley: New York, NY, USA, 1973; pp. 67-96.

2. Durney, D.W. Pressure solution and crystallization deformation. Philos. Trans. R. Soc. Lond. 1976, A283, 229-240. [CrossRef]

3. Beach, A. The geometry of en-echelon vein arrays. Tectonophysics 1975, 28, 245-263. [CrossRef]

4. Bons, P.D. The formation of large quartz veins by rapid ascent of fluids in mobile hydrofractures. Tectonophysics 2001, 336, 1-17. [CrossRef]

5. Bons, P.D.; Elburg, M.A.; Gomez-Rivas, E. A review of the formation of tectonic veins and their microstructures. J. Struct. Geol. 2012, 43, 33-62. [CrossRef]

6. Fisher, D.; Byrne, T. The character and distribution of mineralized fractures in the Kodiak Formation, Alaska: Implications for fluid flow in an underthrust sequence. J. Geophys. Res. 1990, 95, 9069-9080. [CrossRef]

7. McCaffrey, K.; Lonergan, L.; Wilkinson, J. Fractures, Fluid Flow and Mineralization; Geological Society of London Special Publication: London, UK, 1999; 155p.

8. Richards, J.P.; Tosdal, R.M. Structural controls on ore genesis. Rev. Econ. Geol. 2001, 14, 181.

9. Smith, J.V. En echelon sigmoidal vein arrays hosted by faults. J. Struct. Geol. 1996, 18, 1173-1179. [CrossRef]

10. Smith, J.V. Geometry and kinematics of convergent conjugate vein array systems. J. Struct. Geol. 1996, 18, 1291-1300. [CrossRef]

11. Cox, S.F. Deformational controls on the dynamics of fluid flow in mesothermal gold systems. In Fractures, Fluid Flow and Mineralization; McCaffrey, K., Lonergan, L., Wilkinson, J., Eds.; Geological Society of London Special Publication: London, UK, 1999; Volume 155, pp. 123-140.

12. Spencer, S. The use of syntectonic fibres to determine strain estimates and deformation paths: An appraisal. Tectonophysics 1991, 194, 13-34. [CrossRef]

13. Hilgers, C.; Urai, J.L. Microstructural observations on natural syntectonic fibrous veins: Implications for the growth process. Tectonophysics 2002, 352, 257-274. [CrossRef]

14. Barker, S.L.L.; Cox, S.F.; Eggins, S.M.; Gagan, M.K. Microchemical evidence for episodic growth of antitaxial veins during fracture-controlled fluid flow. Earth Planet. Sci. Lett. 2006, 250, 331-344. [CrossRef]

15. Dowling, K.; Morrison, G. Application of quartz textures to the classification of gold deposits using North Queensland examples. Econ. Geol. Monogr. 1990, 6, 342-255.

16. Dong, G.; Morrison, G.; Jaireth, S. Quartz textures in epithermal veins, Queensland-Classification, origin, and implication. Econ. Geol. 1995, 90, 1841-1856. [CrossRef] 
17. Taylor, R. Ores Textures, Recognition and Interpretation; Economic Geology Research Unit and Springer: Berlin, Germany, 2009; 288p.

18. Funedda, A.; Naitza, S.; Buttau, C.; Cocco, F.; Dini, A. Structural Controls of Ore Mineralization in a Polydeformed Basement: Field Examples from the Variscan Baccu Locci Shear Zone (SE Sardinia, Italy). Minerals 2018, 8, 456. [CrossRef]

19. De Roo, J.A. Mass transfer and preferred orientation development during extensional microcracking in slate-belt folds, Elura Mine, Australia. J. Metamorph. Geol. 1989, 7, 311-322. [CrossRef]

20. Davis, B.K.; Hippertt, J.F.M. Relationships between gold concentration and structure in quartz veins fr'om the Hodgkinson Province, northeastern Australia. Miner. Depos. 1998, 33, 391-405. [CrossRef]

21. Forde, A. The late orogenic timing of mineralisation in some slate belt gold deposits, Victoria, Australia. Miner. Depos. 1991, 26, 257-266. [CrossRef]

22. Cox, S.F.; Knackstedt, M.A.; Braun, J. Principles of structural control on permeability and fluid flow in hydrothermal systems. In Structural Controls on Ore Genesis; Richards, J.P., Tosdal, R.M., Eds.; Reviews in Economic Geology; Society of Economic Geologists: Littleton, CO, USA, 2001; Volume 14, pp. 1-24.

23. Gratier, J.P.; Vialon, P. Deformation pattern in a heterogeneous material: Folded and cleaved sedimentary cover immediately overlying a crystalline basement (Oisans, French Alps). Tectonophysics 1980, 65, 151-180. [CrossRef]

24. Chauvet, A.; Onézime, J.; Charvet, J.; Barbanson, L.; Faure, M. Syn- to late-tectonic stockwork emplacement within the Spanish section of the Iberian Pyrite Belt: Structural, textural and mineralogical constraints in the Tharsis-La Zarza areas. Econ. Geol. 2004, 99, 1781-1792. [CrossRef]

25. Cox, S.F.; Etheridge, M.A. Crack-seal fibre growth mechanism and their significance in the development of oriented layer silicate microstructures. J. Struct. Geol. 1983, 92, 147-170. [CrossRef]

26. Fisher, D.M.; Brantley, S.L. Models of quartz overgrowth and vein formation: Deformation and episodic fluid flow in an ancient subduction zone. J. Geoph. Res. 1992, 97, 20043-20061. [CrossRef]

27. Hilgers, C.; Köhn, D.; Bons, P.D.; Urai, J.L. Development of crystal morphology during unitaxial growth in a progressively widening vein: II. Numerical simulations of the evolution of antitaxial fibrous veins. J. Struct. Geol. 2001, 23, 873-885. [CrossRef]

28. Ramsay, J.G. The crack-seal mechanism of rock deformation. Nature 1980, 284, 135-139. [CrossRef]

29. Cox, S.F. Antitaxial crack-seal vein microstructures and their relationship to displacement paths. J. Struct. Geol. 1987, 9, 779-787. [CrossRef]

30. Hilgers, C.; Urai, J.L. On the arrangement of solid inclusions in fibrous veins and the role of the crack-seal mechanism. J. Struct. Geol. 2005, 27, 481-494. [CrossRef]

31. Boullier, A.M.; Robert, F. Paleoseismic events recorded in Archean gold quartz vein networks, Val-Dor, Abitibi, Quebec, Canada. J. Struct. Geol. 1992, 14, 161-177. [CrossRef]

32. Bons, P.D.; Jessell, M.W. Experimental simulation of the formation of fibrous veins by localised dissolution-precipitation creep. Mineral. Mag. 1997, 61, 53-63. [CrossRef]

33. Jébrak, M. Hydrothermal breccias in vein-type ore deposits: A review of mechanisms, morphology and size distribution. Ore Geol. Rev. 1997, 12, 111-134. [CrossRef]

34. Sibson, R.H. Brecciation Processes in Fault Zones: Inferences from Earthquake Rupturing. Pure Appl. Geophys. 1986, 124, 159-175. [CrossRef]

35. Taylor, R.G.; Pollard, P.J. Mineralized Breccia Systems-Methods of Recognition and Interpretation, Economic Geology Research Unit Contribution 46; James Cook University of North Queensland: Douglas, Australia, 1993; $36 \mathrm{p}$.

36. Clark, C.; James, P. Hydrothermal brecciation due to fluid pressure fluctuations: Examples from the Olary Domain, South Australia. Tectonophysics 2003, 366, 187-206. [CrossRef]

37. Tarasewicz, J.P.T.; Woodcok, N.H.; Disckson, J.A.D. Carbonate dilation breccias: Examples from the damage zone to the Dent Fault, northwest England. Geol. Soc. Am. Bull. 2005, 117, 736-745. [CrossRef]

38. Davies, A.G.S.; Cooke, D.R.; Gemmell, J.B.; Van Leeuwen, T.; Cesare, P.; Hartshorn, G. Hydrothermal Breccias and Veins at the Kelian Gold Mine, Kalimantan, Indonesia: Genesis of a Large Epithermal Gold Deposit. Econ. Geol. 2008, 103, 717-757. [CrossRef]

39. Woodcok, N.H.; Mort, K. Classification of fault breccias and related fault rocks. Geol. Mag. 2008, 145, 435-440. [CrossRef] 
40. Burchfiel, B.C.; Stewart, J.H. "Pull-apart” origin of the central segment of Death Valley, California. Geol. Soc. Am. Bull. 1966, 77, 439-442. [CrossRef]

41. Chauvet, A.; Piantone, P.; Barbanson, L.; Nehlig, P.; Pedroletti, I. Gold deposit formation during collapse tectonics: Structural, mineralogical, geochronological, and fluid inclusion constraints in the Ouro Preto gold mines, Quadrilátero Ferrífero, Brazil. Econ. Geol. 2001, 96, 25-48. [CrossRef]

42. Souza Martins, B.; Lobato, L.M.; Rosière, C.A.; Hagemann, S.G.; Schneider Santos, J.O.; dos Santos Peixoto Villanova, F.L.; Figueiredo e Silva, R.C.; de Ávila Lemos, L.H. The Archean BIF-hosted Lamego gold deposit, Rio das Velhas greenstone belt, Quadrilátero Ferrífero: Evidence for Cambrian structural modification of an Archean orogenic gold deposit. Ore Geol. Rev. 2016, 72, 963-988. [CrossRef]

43. Kerrich, R. Geodynamic setting and hydraulic regimes: Shear zone hosted mesothermal gold deposits. In Mineralisation and Shear Zones; Bursnall, J.T., Ed.; Geological Association of Canada Short Course Notes; Mineralogical Association of Canada: Quebec City, QC, Canada, 1989; Volume 6, pp. 89-128.

44. Poulsen, K.H.; Robert, F. Shear Zones and Gold: Practical Examples from the Southern Canadian Shield. In Mineralisation and Shear Zones; Bursnall, J.T., Ed.; Geological Association of Canada Short Course Notes; Mineralogical Association of Canada: Quebec City, QC, Canada, 1989; Volume 6, pp. 239-266.

45. Cabral, A.R.; Zeh, A. Detrital zircon without detritus: A result of 496-Ma-old fluid-rock interaction during the gold-lode formation of Passagem, Minas Gerais, Brazil. Lithos 2015, 212-215, 415-427. [CrossRef]

46. Cassard, D.; Chauvet, A.; Bailly, L.; Llosa, F.; Rosas, J.; Marcoux, E.; Lerouge, C. Structural control and K/Ar dating of the Au-Ag epithermal veins in the Shila Cordillera, southern Peru. C. R. Acad. Sci. Paris 2000, 330, 23-30. [CrossRef]

47. Chauvet, A.; Bailly, L.; André, A.S.; Moni\#xE9;, P.; Cassard, D.; Llosa Tajada, F.; Rosas Vargas, J.; Tuduri, J. Internal vein texture and vein evolution of the epithermal Shila-Paula district, southern Peru. Miner. Depos. 2006, 41, 387-410. [CrossRef]

48. Onézime, J.; Charvet, J.; Faure, M.; Bourdier, J.L.; Chauvet, A. A new geodynamic interpretation for the South Portuguese Zone (SW Iberia) and the Iberian Pyrite Belt genesis. Tectonics 2003, 22, 1027. [CrossRef]

49. Barbanson, L.; Chauvet, A.; Gaouzi, A.; Badra, L.; Mechiche, M.; Touray, J.C.; Oukarou, S. Les minéralisations Cu-(Ni-Bi-U-Au-Ag) d'Ifri (district du Haut Seksaoua, Maroc): Apport de l'étude texturale au débat syngenèse versus épigenèse. C. R. Géosci. 2003, 335, 1021-1029. [CrossRef]

50. Gaouzi, A.; Chauvet, A.; Barbanson, L.; Badra, L.; Touray, J.C.; Oukarou, S.; El Wartiti, M. Mise en place syntectonique des minéralisations cuprifères du gîte d'Ifri (District du Haut Seksaoua, Haut-Atlas occidental, Maroc). C. R. Acad. Sci. Paris 2001, 333, 277-284.

51. Chauvet, A.; Barbanson, L.; Gaouzi, A.; Badra, L.; Touray, J.C.; Oukarou, S. Example of a structurally controlled copper deposit from ther Hercynian Western High-Atlas (Morocco): The High Seksaoua mining district. In The Timing and Location of Major Ore Deposits in an Evolving Orogen; Blundell, D.J., Neuber, F., Von Quadt, A., Eds.; Geological Society of London Special Publication: London, UK, 2002; Volume 204, pp. 247-271.

52. Mahjoubi, E.M.; Chauvet, A.; Badra, L.; Sizaret, S.; Barbanson, L.; El Maz, A.; Chen, Y.; Amman, M. Structural, mineralogical, and paleoflow velocity constraints on Hercynian tin mineralization: The Achmmach prospect of the Moroccan Central Massif. Miner. Depos. 2015, 51, 431-451. [CrossRef]

53. Chauvet, A.; Volland-Tuduri, N.; Lerouge, C.; Bouchot, V.; Monié, P.; Charonnat, X.; Faure, M. Geochronological and geochemical characterization of magmatic-hydrothermal events within the southern Variscan external domain. Intern. J. Earth Sci. 2012, 101, 69-86. [CrossRef]

54. Poulsen, K.H.; Robert, F.; Dubé, B. Geological Classification of Canadian Gold Deposits; Geological Survey of Canada, Bulletin: Ottawa, ON, Canada, 2000; Volume 540, 113p.

55. Bouchot, V.; Milési, J.P.; Lescuyer, J.L.; Ledru, P. Les minéralisations aurifères de la France dans leur cadre géologique autour de 300 Ma. Chron. Rech. Min. 1997, 528, 13-62.

56. Bouchot, V.; Ledru, P.; Lerouge, C.; Lescuyer, J.L.; Milési, J.P. Late Variscan mineralizing systems related to orogenic processes: The French Massif. Ore Geol. Rev. 2005, 27, 169-197. [CrossRef]

57. Gloaguen, E. Apport D’une Étude Intégrée sur les Relations Entre Granites et Minéralisations Filoniennes (Au et $\mathrm{Sn}-\mathrm{W}$ ) en Contexte Tardi Orogénique (Chaîne Hercynienne, Galice Centrale, Espagne). Ph.D. Thesis, University of Orléans, Orléans, France, 2006. 
58. Gloaguen, E.; Branquet, Y.; Chauvet, A.; Bouchot, V.; Barbanson, L.; Vigneresse, J.L. Tracing the magmatic/hydrothermal transition in regional low-strain zones: The role of magma dynamics in strain localization at pluton roof, implications for intrusion-related gold deposits. J. Struct. Geol. 2014, 58, 108-121. [CrossRef]

59. Sizaret, S.; Branquet, Y.; Gloaguen, E.; Chauvet, A.; Barbanson, L.; Arbaret, L.; Chen, Y. Estimating the local paleo-fluid flow velocity: New textural method and application to metasomatism. Earth Planet. Sci. Lett. 2009, 280, 71-82. [CrossRef]

60. Audétat, A.; Günther, D.; Heinrich, C.A. Formation of magmatic-hydrothermal ore deposits: Insights from LA-ICP-MS analysis of fluid inclusions. Science 2008, 279, 2091-2094.

61. Pe-Piper, G.; Piper, D.J.W.; McFarlane, C.R.M.; Sangster, C.; Zhang, Y.; Boucher, B. Petrology, chronology and sequence of vein systems: Systematic magmatic and hydrothermal history of a major intracontinental shear zone, Canadian Appalachians. Lithos 2018, 304-307, 299-310. [CrossRef]

62. Groves, D.I.; Goldfarb, R.J.; Gebre-Mariam, M.; Hagemann, S.; Robert, F. Orogenic gold deposits: A proposed classification in the context of their crustal distribution and relationship to other gold deposit types. Ore Geol. Rev. 1998, 13, 7-27. [CrossRef]

63. Lang, J.R.; Baker, T. Intrusion-related gold systems: The present level of understanding. Miner. Depos. 2001, 36, 477-489. [CrossRef]

64. Everall, T.J.; Sanislav, I.V. The Influence of Pre-Existing Deformation and Alteration Textures on Rock Strength, Failure Modes and Shear Strength Parameters. Geosciences 2018, 8, 124. [CrossRef]

(C) 2019 by the author. Licensee MDPI, Basel, Switzerland. This article is an open access article distributed under the terms and conditions of the Creative Commons Attribution (CC BY) license (http://creativecommons.org/licenses/by/4.0/). 